\title{
Activation of the Wnt/ $\beta$-catenin signaling pathway may contribute to cervical cancer pathogenesis via upregulation of Twist
}

\author{
XIAOHONG SUN and YU LIU \\ Department of Gynecology, Nanhua Hospital Affiliated to Nanhua University, Hengyang, Hunan 421001, P.R. China
}

Received November 17, 2015; Accepted April 25, 2017

DOI: $10.3892 / 01.2017 .6754$

\begin{abstract}
The Wnt signaling pathway regulates a number of biological processes. In the present study, the association between the Wnt signaling pathway and the pathogenesis of cervical cancer was investigated in the human cervical cancer CaSki cell line. An MTT assay was used to screen various concentrations of lithium chloride for use in subsequent experiments. Following incubation of CaSki cells with 0.05 and $0.1 \mathrm{~mol} / 1$ lithium chloride, Twist and $\beta$-catenin were markedly upregulated at the mRNA and protein levels, respectively, compared with the untreated group, as measured by reverse transcription-polymerase chain reaction and western blotting. The results of the present study indicate that Wnt activation (which was induced by lithium chloride) and the subsequent upregulation of Twist may represent one of the molecular mechanisms underlying the occurrence and development of cervical cancer.
\end{abstract}

\section{Introduction}

Cervical cancer is one of the most common malignant tumors and is the second leading cause of cancer-associated mortality in women worldwide (1). A number of factors, including epigenetic, genetic, cellular, and environmental factors, serve important roles in the carcinogenesis and development of cervical cancer (2); however, the precise molecular mechanisms underlying cervical cancer development remain unclear. The Wnt/ $\beta$-catenin signaling pathway has previously been associated with the etiology of cervical cancer $(3,4)$.

The Wnt signaling pathway is an important regulator of a number of biological processes, including cell differentiation in embryogenesis, cell proliferation, cell migration, cell cycle, cell polarity, organogenesis during embryonic development, and tumor progression (5). Previous reports have demonstrated

Correspondence to: Dr Yu Liu, Department of Gynecology, Nanhua Hospital Affiliated to Nanhua University, 336 Dongfeng South Road, Hengyang, Hunan 421001, P.R. China

E-mail: yuliu1116@sina.com

Key words: CaSki cells, cervical cancer, Wnt/ $\beta$-catenin signaling, Twist that aberrant activation of the $\mathrm{Wnt} / \beta$-catenin signaling pathway contributes to the progression of a number of types of human cancer, including colon cancer, hepatocellular cancer and breast carcinoma (6-8). Furthermore, in the majority of cervical cancer specimens, the cytoplasmic and nuclear accumulation of $\beta$-catenin, which is the main hallmark of Wnt activation, has been observed (9).

Twist (also known as Twist family bHLH transcription factor 1) is a member of the highly conserved family of basic helix-loop-helix transcription factors (10). Twist gene expression is upregulated in a number of types of cancer, including prostate, lung and breast cancer (11). The upregulation of Twist is associated with angiogenesis and metastasis (11). In addition, previous reports have suggested that Twist serves a role in tumor metastasis. Fu et al (12) reported that knockdown of Twist prevents lung metastasis in mice.

The purpose of the present study was to further investigate the association between Wnt activation, the subsequent upregulation of Twist and the pathogenesis of cervical cancer. In order to investigate these associations, lithium chloride was used, which is an anti-cancer agent that activates the Wnt/ $\beta$-catenin signaling pathway through inhibition of glycogen synthase kinase $3 \beta$ (GSK3 $\beta$ ) (13).

\section{Materials and methods}

Cell culture. The human cervical cancer cell line CaSki was purchased from the Experiment Center of Central South University (Changsha, China). The cells were cultured in Dulbecco's modified Eagle's medium (American Amereseo, Solon, OH, USA) supplemented with $10 \%$ fetal bovine serum (Hangzhou Sijiqing Biological Engineering Materials Co., Ltd., Hangzhou, China), $100 \mu \mathrm{g} / \mathrm{ml}$ penicillin and $100 \mathrm{U} / \mathrm{ml}$ streptomycin at $37^{\circ} \mathrm{C}$ in a humidified atmosphere with $5 \%$ $\mathrm{CO}_{2}$. Cell cultures were cultured at the Laboratory of Tumor Research in South China University (Guangzhou, China).

MTT assay. CaSki cells $\left(1 \times 10^{5}\right.$ cells $\left./ \mathrm{ml}\right)$ were seeded into 96-well plates and grown at $37^{\circ} \mathrm{C}$ for $48 \mathrm{~h}$. Freshly prepared lithium chloride (Sigma-Aldrich; Merck KGaA, Darmstadt, Germany) was then added (final concentrations: 0, 0.025, 0.05, $0.1,0.2,0.4$ or $0.8 \mathrm{~mol} / \mathrm{l})$. After $2 \mathrm{~h}$ incubation at $37^{\circ} \mathrm{C}$, cell viability was assessed using an MTT assay according to the manufacturer's protocol. A total of $100 \mathrm{ml} 2 \% \mathrm{MTT}$ reagent was added to each well. Cells were cultured for $4 \mathrm{~h}$ in $37^{\circ} \mathrm{C}$ 
in a $\mathrm{CO}_{2}$ incubator then the medium was removed. Cells were washed with PBS twice, $500 \mu$ l DMSO was added and cells were agitated at a low speed for $10 \mathrm{~min}$ at room temperature. The absorbance at $490 \mathrm{~nm}$ of each well was measured using a spectrophotometer after 12 and $24 \mathrm{~h}$.

Reverse transcription-polymerase chain reaction ( $R T-P C R)$. Total RNA was isolated from the lithium chloride-treated or untreated CaSki cells using the Qiagen RNeasy kit (Qiagen, Inc., Valencia, CA, USA) and then reverse transcribed using a Reverse Transcription system (Promega Corporation, Madison, WI, USA), according to the manufacturer's protocol. The resulting complementary DNA $(20 \mu \mathrm{l})$ was amplified using a PCR kit (Thermo Fisher Scientific, Inc., Waltham, MA, USA) with primers specific for Twist (NM_000474.3; forward, 5'-CCT TCTCGGTCTGGAGGATG-3' and reverse, 5'-AGGAAGGCT GGAAGAGTGC-3'), and $\beta$-actin (forward, 5'-CTGGGACGA CATGGAGAAAA-3' and reverse, 5'-AGGAAGGCTGGAAGA GTGC-3') was amplified as an endogenous control. The PCR conditions for Twist were as follows: Initial denaturation at $94^{\circ} \mathrm{C}$ for $5 \mathrm{~min}$; 35 cycles of denaturation at $94^{\circ} \mathrm{C}$ for $30 \mathrm{sec}$, annealing at $60^{\circ} \mathrm{C}$ for $30 \mathrm{sec}$ and extension at $72^{\circ} \mathrm{C}$ for $40 \mathrm{sec}$; and final extension at $72^{\circ} \mathrm{C}$ for $2 \mathrm{~min}$. The PCR conditions for $\beta$-actin were as follows: Initial denaturation at $94^{\circ} \mathrm{C}$ for $5 \mathrm{~min} ; 35$ cycles of denaturation at $94^{\circ} \mathrm{C}$ for $30 \mathrm{sec}$, annealing at $51^{\circ} \mathrm{C}$ for $30 \mathrm{sec}$ and extension at $72^{\circ} \mathrm{C}$ for $42 \mathrm{sec}$; and final extension at $72^{\circ} \mathrm{C}$ for $2 \mathrm{~min}$. The qPCRs were run on a $1.5 \%$ agarose gel and a Gel Imaging Analysis system (Shanghai Tocan Bio-Technology Co., Ltd. Shanghai, China) was used to observe the results. An AlphaImager ${ }^{\text {TM }} 2200$ system (ProteinSimple; Bio-Techne, Minneapolis, MN, USA) was used to analyze the results.

Western blot analysis. CaSki cells were harvested and homogenized with lysis buffer (Sigma-Aldrich; Merck KGaA). The protein extract $(50 \mu \mathrm{g} /$ lane $)$ was separated on a $12 \%$ SDS-PAGE gel and transferred to nitrocellulose membranes (EMD Millipore, Billerica, MA, USA). Following blocking with $10 \%$ nonfat dry milk in TBS, the membrane was probed with a primary monoclonal antibody specific to $\beta$-catenin (dilution, 1:1,000; cat no. sc-7963) or $\beta$-actin (dilution, 1:1,000; cat no. sc-130656) (both from Santa Cruz Biotechnology, Inc., Dallas, TX, USA) which was used as an internal control for protein loading. The membrane was further probed with horseradish peroxidase-conjugated goat anti-mouse IgG (dilution, 1:2,000; Santa Cruz Biotechnology, Inc.) and the protein bands were visualized using Pierce ${ }^{\mathrm{TM}}$ ECL western blotting substrate (Thermo Fisher Scientific, Inc.) and analyzed using ImageJ software (version 1.48u; National Institutes of Health, Bethesda, MD, USA).

Statistical analysis. SPSS software (version 18.0; SPSS, Inc., Chicago, IL, USA) was used for statistical analysis. Each experiment was repeated $\geq 3$ times. Student's t-tests and Tukey's post hoc test were performed. $\mathrm{P}<0.05$ was considered to indicate a statistically significant difference.

\section{Results}

Determination of lithium chloride concentration. To study the association between the Wnt signaling system and the

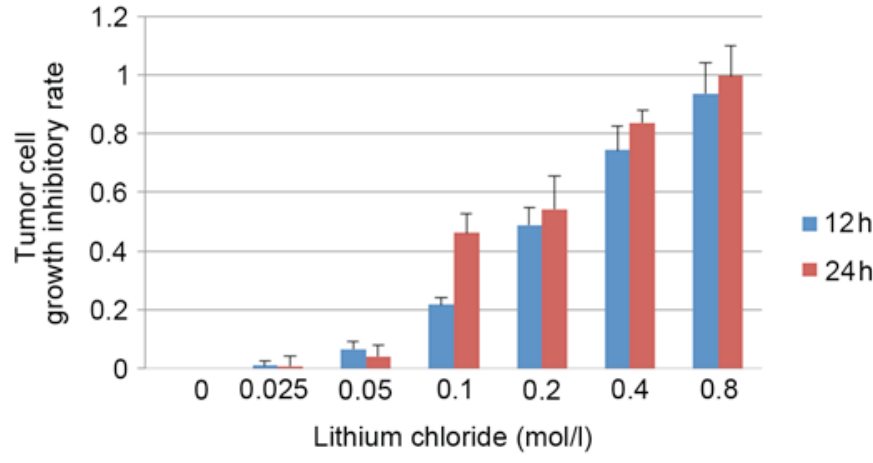

Figure 1. MTT assay to screen for a suitable lithium chloride concentration for subsequent experiments. Data are presented as the mean \pm standard deviation following three repeats.

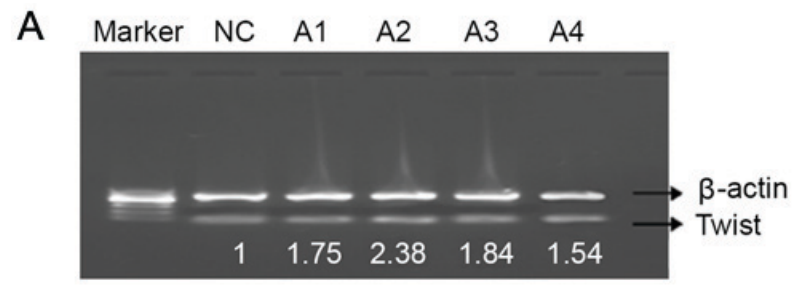

B

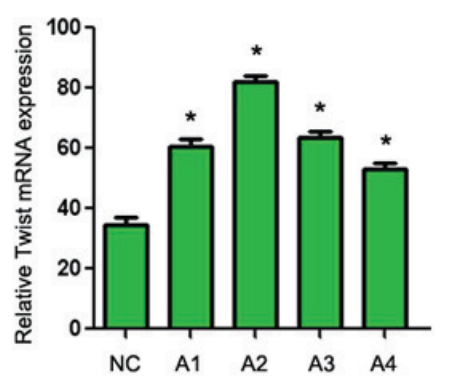

Figure 2. Reverse transcription-polymerase chain reaction analysis of Twist expression following treatment with different concentrations of lithium chloride for different time periods. (A) Representative gel with $\beta$-actin used as a loading control. Lanes: NC, untreated cells; A1, $0.05 \mathrm{~mol} / 1,12 \mathrm{~h}$; A2, $0.05 \mathrm{~mol} / 1,24 \mathrm{~h}$; A3, $0.1 \mathrm{~mol} / 1,12 \mathrm{~h}$; A4, $0.1 \mathrm{~mol} / 1,12 \mathrm{~h}$. (B) Quantification of Twist mRNA expression. Data are presented as the mean \pm standard deviation following three repeats. $\mathrm{P}<0.05$ compared with negative control.

pathogenesis of cervical cancer, CaSki cells were treated with lithium chloride. An MTT cell viability assay was performed to screen for a suitable lithium chloride concentration. The absorbance values of the lithium chloride-treated group and control group were determined by MTT assay in order to calculate the growth inhibitory rate of CaSki cells at 24 and $48 \mathrm{~h}$ (Fig. 1). Concentrations of 0.05 and $0.1 \mathrm{~mol} / 1$ lithium chloride were selected for subsequent experiments.

Twist and $\beta$-catenin are upregulated in CaSki cells following treatment with lithium chloride. CaSki cells were treated with 0.05 and $0.1 \mathrm{~mol} / 1$ lithium chloride (final concentration) for 24 and $48 \mathrm{~h}$. RT-PCR analysis demonstrated that the mRNA level of Twist was markedly increased in lithium chloride treated cells (Fig. 2; lanes A1-A4) compared with the untreated cells. In addition, western blot analysis demonstrated a marked increase in $\beta$-catenin protein expression in lithium chloride treated cells (Fig. 3; lanes A1-A4) compared with the untreated 
A

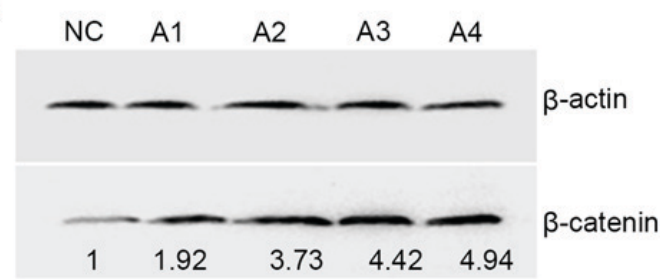

B

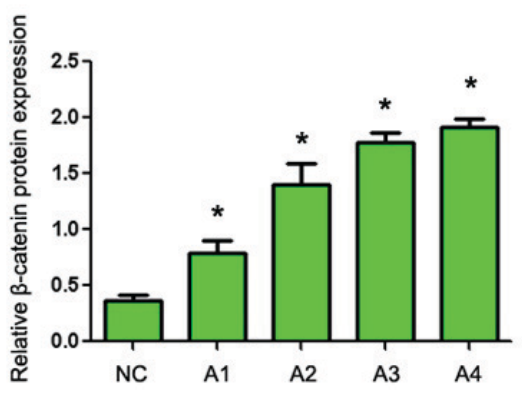

Figure 3. Western blot analysis of $\beta$-catenin expression following treatment with different concentrations of lithium chloride for different time periods. (A) Representative gel with $\beta$-actin used as a loading control. Lanes: NC, untreated cells; A1, $0.05 \mathrm{~mol} / 1,12 \mathrm{~h}$; A2, $0.05 \mathrm{~mol} / 1,24 \mathrm{~h}$; A3, $0.1 \mathrm{~mol} / 1$, $12 \mathrm{~h} ; \mathrm{A} 4,0.1 \mathrm{~mol} / 1,12 \mathrm{~h}$. (B) Quantification of $\beta$-catenin protein expression. Data are presented as the mean \pm standard deviation following three repeats ${ }^{*} \mathrm{P}<0.05$ compared with negative control.

cells. These results demonstrate that lithium chloride activates the $\mathrm{Wnt} / \beta$-catenin signaling pathway in the human cervical cancer CaSki cell line.

\section{Discussion}

The Wnt/ $\beta$-catenin signaling pathway has been reported to be involved in tumorigenesis of a number of types of cancer, including cervical, ovarian, breast and oral cancer (14). In addition, a number of studies have suggested roles for the Wnt $/ \beta$-catenin signaling pathway-associated proteins $\beta$-catenin, GSK3 $\beta$, adenomatous polyposis coli protein, Wnt and T-cell factor/lymphoid enhancer factor (TCF/LEF) in cervical cancer progression $(15,16)$. The main hallmark of Wnt activation is the cytoplasmic and nuclear accumulation of $\beta$-catenin (17). Ying and Tao (18) previously reported the cytoplasmic and nuclear accumulation of $\beta$-catenin in cervical cancer specimens. Stabilized $\beta$-catenin translocates to the nucleus and forms a complex with TCF/LEF to activate the Wnt signaling pathway (16). The abnormal activation of Wnt signaling pathway can induce the nuclear accumulation of $\beta$-catenin (17). Lithium chloride inhibits the activity of GSK3 $\beta$, consequently inhibiting GSK3 $\beta$-induced cervical cancer cell proliferation through blockade of the Wnt/ $\beta$-catenin signaling pathway $(13,19)$. In addition, Fadare et al $(20)$ reported the increased expression of $\beta$-catenin in cervical cancer; lithium chloride caused Wnt activation and subsequently led to the increased accumulation of cytosolic and nuclear $\beta$-catenin with consequent upregulation of Wnt target genes.

The present study focused on the role of the Wnt/ $\beta$-catenin signaling pathway in the progression of cervical cancer. Human cervical cancer CaSki cells treated with the anti-cancer agent lithium chloride exhibited a marked increase in the expression of $\beta$-catenin and Twist. It has previously been reported that Twist acts as oncogene and induces cancer cell proliferation in a number of types of cancer (21). In addition, Twist has potential roles in tumor metastasis (22); however, further studies are required to elucidate the role of Twist in cervical cancer progression.

In conclusion, the present study demonstrated increased expression of Twist and $\beta$-catenin in lithium chloride-treated CaSki cells. The results indicate that Wnt activation (which was induced by lithium chloride) and the subsequent upregulation of Twist may represent one of the molecular mechanisms underlying the occurrence and development of cervical cancer.

\section{References}

1. Parkin DM and Bray F: Chapter 2: The burden of HPV-related cancers. Vaccine 24 (Suppl 3): S3/11-25, 2006.

2. Parkin DM, Bray F, Ferlay J and Pisani P: Estimating the world cancer burden: Globocan 2000. Int J Cancer 94: 153-156, 2001.

3. Uren A, Fallen S, Yuan H, Usubutun A, Kücükali T, Schlegel R and Toretsky JA: Activation of the canonical Wnt pathway during genital keratinocyte transformation: A model for cervical cancer progression. Cancer Res 65: 6199-6206, 2005.

4. Perez-Plasencia C, Duenas-Gonzalez A and Alatorre-Tavera B: Second hit in cervical carcinogenesis process: Involvement of wnt/beta catenin pathway. Int Arch Med 1: 10, 2008.

5. MacDonald BT, Tamai K and He X: Wnt/beta-catenin signaling: Components, mechanisms, and diseases. Dev Cell 17: 9-26, 2009.

6. Xufeng Z, Liang Y and Yi L: Wnt/ $\beta$-catenin signaling pathway and its role in hepatocellular carcinoma. Front Med China 2: 216-228, 2008.

7. Tan Z, Zheng H, Lin X, Zhang W, Zhu J, Wu G, Cao L, Song J, Wu S, Song L and Li J: MicroRNA-1229 overexpression promotes cell proliferation and tumorigenicity and activates Wnt/ $\beta$-catenin signaling in breast cancer. Oncotarget 7 : 24076-24087, 2016.

8. Chikazawa N, Tanaka H, Tasaka T, Nakamura M, Tanaka M, Onishi $\mathrm{H}$ and Katano M: Inhibition of Wnt signaling pathway decreases chemotherapy-resistant side-population colon cancer cells. Anticancer Res 30: 2041-2048, 2010.

9. Shinohara A, Yokoyama Y, Wan X, Takahashi Y, Mori Y, Takami T, Shimokawa K and Tamaya T: Cytoplasmic/nuclear expression without mutation of exon 3 of the beta-catenin gene is frequent in the development of the neoplasm of the uterine cervix. Gynecol Oncol 82: 450-455, 2001.

10. Yang J, Mani SA, Donaher JL, Ramaswamy S, Itzykson RA, Come C, Savagner P, Gitelman I, Richardson A and Weinberg RA: Twist, a master regulator of morphogenesis, plays an essential role in tumor metastasis. Cell 117: 927-939, 2004.

11. Bastid J, Ciancia C, Puisieux A and Ansieau S: Role of TWIST proteins in cancer progression. Atlas Genet Cytogenet Oncol Haematol 14: 898-944, 2010.

12. Fu J, Qin L, He T, Qin J, Hong J, Wong J, Liao L and Xu J: The TWIST/Mi2/NuRD protein complex and its essential role in cancer metastasis. Cell Res 21: 275-289, 2011.

13. Hiyama A, Sakai D, Arai F, Nakajima D, Yokoyama K and Mochida J: Effects of a glycogen synthase kinase-3 $\beta$ inhibitor $(\mathrm{LiCl})$ on $\mathrm{c}-\mathrm{myc}$ protein in intervertebral disc cells. J Cell Biochem 112: 2974-2986, 2011.

14. Benary U, Kofahl B, Hecht A and Wolf J: Modeling Wnt/ $\beta$-catenin target gene expression in APC and Wnt gradients under wild type and mutant conditions. Front Physiol 4: 21, 2013.

15. Bahrami A, Hasanzadeh M, ShahidSales S, Yousefi Z, Kadkhodayan S, Farazestanian M, Joudi Mashhad M, Gharib M, Hassanian SM and Avan A: Clinical significance and prognosis value of Wnt signaling pathway in cervical cancer. J Cell Biochem: Mar 16, 2017 (Epub ahead of print). doi: 10.1002/jcb.25992.

16. Wang F, Huang W, Hu X, Chen C, Li X, Qiu J, Liang Z, Zhang J, Li L, Wang X, et al: Transcription factor AP- $2 \beta$ suppresses cervical cancer cell proliferation by promoting the degradation of its interaction partner $\beta$-catenin. Mol Carcinog 56: 1909-1923, 2017. 
17. Ormanns S, Neumann J, Horst D, Kirchner T and Jung A: WNT signaling and distant metastasis in colon cancer through transcriptional activity of nuclear $\beta$-catenin depend on active PI3K signaling. Oncotarget 5: 2999-3011, 2014.

18. Ying Y and Tao Q: Epigenetic disruption of the WNT/beta-catenin signaling pathway in human cancers. Epigenetics 4: 307-312, 2009.

19. Klein PS and Melton DA: A molecular mechanism for the effect of lithium on development. Proc Natl Acad Sci USA 93 8455-8459, 1996.

20. Fadare O, Reddy H, Wang J, Hileeto D, Schwartz PE and Zheng W: E-cadherin and beta-catenin expression in early stage cervical carcinoma: A tissue microarray study of 147 cases. World J Surg Oncol 3: 38, 2005.
21. Yang L, Hou Y, Yuan J, Tang S, Zhang H, Zhu Q, Du YE, Zhou M, Wen S, Xu L, et al: Twist promotes reprogramming of glucose metabolism in breast cancer cells through PI3K/AKT and p53 signaling pathways. Oncotarget 6: 25755-25769, 2015.

22. DiMeo TA, Anderson K, Phadke P, Fan C, Perou CM, Naber S and Kuperwasser C: A novel lung metastasis signature links Wnt signaling with cancer cell self-renewal and epithelial-mesenchymal transitionin basal-like breast cancer. Cancer Res 69: 5364-5373, 2009. 